\title{
Penggunaan Bakteri Asam Laktat dan Inulin terhadap Ketahanan Tubuh, Kecernaan Nutrien dan Performan Itik Tegal Jantan Periode Starter
}

\section{Feeding Of Lactic Acid Bacteria and Inulin on Body Resistance, Digestibility Nutrient and Performance Of Male Tegal Duck Starter Period}

\author{
Lilik Krismiyanto $^{1}$ *, Istna Mangisah ${ }^{2}$, Nyoman Suthama ${ }^{3}$ dan Hanny Indrat Wahyuni ${ }^{4}$ \\ 1,2,3,4 Departemen Peternakan, Fakultas Peternakan dan Pertanian, Universitas Diponegoro, \\ Kampus Tembalang, Semarang 50275, Jawa Tengah \\ *Corresponding author : lilikkrismiyanto@gmail.com
}

Sejarah artikel : Menerima : 05 Juni $2020 \quad$ Revisi : 11 Juni $2020 \quad$ Diterima : 20 Juni $2020 \quad$ Online : 25 Juni 2020

\begin{abstract}
ABSTRAK
Penelitian bertujuan untuk mengetahui pengaruh penggunaan starter bakteri asam laktat (BAL) dan inulin bersumber dari umbi bunga dahlia (Dahlia variabilis) terhadap ketahanan tubuh, kecernaan nutrien dan performan itik tegal jantan periode starter. Itik tegal jantan berjumlah 96 ekor umur 8 hari, starter BAL bentuk cair dan inulin bersumber dari tepung umbi bunga dahlia (TUBD) digunakan pada penelitian ini. Rancangan Penelitian adalah rancangan acak lengkap dengan 4 perlakuan dan 4 ulangan. Masing-masing ulangan terdiri dari 6 ekor itik. Perlakuan yang diterapkan: T0 (ransum kontrolRK), T1 (RK $+2 \mathrm{~mL}$ starter BAL), T2 (RK + 0,8\% TUBD), dan T3 (RK $+2 \mathrm{~mL}$ starter BAL dan $0,8 \%$ TUBD). Parameter yang diukur meliputi konsumsi ransum, kecernaan protein kasar, serat kasar, lemak kasar, asupan protein, rasio heterofil/limfosit $(\mathrm{H} / \mathrm{L})$, konversi ransum dan pertambahan bobot badan. Data dianalisis ragam dan dilanjutkan dengan uji wilayah ganda Duncan $5 \%$. Hasil penelitian bahwa kombinasi starter BAL dan TUBD nyata $(P<0,05)$ meningkatkan kecernaan protein kasar, serat kasar, lemak kasar, asupan protein, rasio H/L, konversi ransum dan pertambahan bobot badan, tetapi menurunkan konsumsi ransum. Kesimpulan penelitian adalah kombinasi starter BAL $2 \mathrm{~mL}$ dan TUBD $0,8 \%$ (T3) menghasilkan ketahanan tubuh, kecernaan nutrien dan performan lebih baik.
\end{abstract}

Kata Kunci : Bakteri asam laktat, inulin umbi bunga dahlia, itik tegal jantan, kecernaan nutrien

\section{ABSTRACT}

The research aims to determine the effect of dietary dahlia flower tuber powder as an inulin source and lactic acid bacteria (LAB) starter on body resistance, nutrient digestibility and performance in Tegal male ducks. A summary of 96 birds of 8 days Tegal male ducks, LAB starter and dahlia flower tuber powder (DFTP) as a source of inulin were used in this study. The research design was a completely randomized design with 4 treatments and 4 replications. Each replication consisted of 6 birds. Dietary treatments were the inclusion levels of DFTP, namely: T0 (control diet/CD), T1 (CD+2 mL LAB starter), T2 (CD+0.8\% powder of DFTP) and T3 (CD+2 mL LAB starter and $0.8 \%$ DFTP). Parameters measured were feed intake, protein, fat and crude fiber digestibility, protein intake, heterophil/lymphocytes $(\mathrm{H} / \mathrm{L})$ ratio, feed conversion ratio and daily body weight. Data were subjected to analysis of variance and continued to Duncan test $5 \%$. Results indicated that feeding $2 \mathrm{~mL}$ LAB starter and 0,8\% DFTP as an inulin source significantly $(P<0.05)$ increased the feed intake, protein, fiber and fat digestibility, protein intake, $\mathrm{H} / \mathrm{L}$ ratio, feed conversion ratio and daily body weight. In conclusion, feeding starter $\mathrm{LAB}$ and DFTP (T3) provides body resistance, nutrient digestibility and performance is better.

Key words : Inulin of dahlia flower tuber, lactic acid bacteria, nutrien digestibility, tegal male duck 


\section{PENDAHULUAN}

Populasi itik di Jawa Tengah berdasarkan data badan pusat statistik (BPS) peternakan Jawa Tengah mengalami peningkatan sejak tahun 2010-2019 sebesar 5.006.163 -

6.822.607 atau 3,14\% (Direktorat Jenderal Peternakan dan Kesehatan Hewan, 2019). Itik berpotensi tinggi untuk dikembangkan sebagai produksi telur dan daging. Selain permintaan telur yang meningkat digunakan sebagai olahan makanan seperti telur asin, permintaan daging itik pun juga tinggi. Oleh sebab itu, perlu adanya manajemen untuk mengimbangi permintaan daging itik di masyarakat.

Kendala dalam mempersiapkan daging itik perlu adanya manajemen yang baik untuk mendukung kebutuhan protein daging. Guna mengatasi kendala tersebut perlu adanya perbaikan kualitas ransum. Itik pedaging periode starter kebutuhan protein dan energi metabolis sebesar 20\% dan 2.850 kkal/kg (Standar Nasional Indonesia, 2018). Kebutuhan nutrien itik tegal jantan, meskipun berdasarkan asumsi sudah dilakukan perbaikan formulasi ransum, tetapi masih diperlukan upaya untuk meningkatkan efisiensi produksi. Manipulasi ransum merupakan satu cara untuk meningkatkan efisiensi ransum guna meningkatkan kemampuan produksi. Periode starter merupakan masa yang penting untuk perkembangan fisiologis saluran pencernaan. Pemberian ransum yang berkualitas dapat meningkatkan kecernaan nutrien dan performan produksi.

Manipulasi ransum pada itik tegal jantan dapat dilakukan dengan penambahan sumber aditif alami. Penambahan aditif yang biasanya diberikan peternak masih menggunakan antibiotik atau obat-obatan, sehingga dikhawatirkan mempunyai dampak negatif terhadap kehidupan bakteri (bakteri resisten) pada saluran pencernaan dan juga menimbulkan residu pada produk daging yang membahayakan konsumen. Oleh sebab itu, diupayakan penambahan aditif alami berupa probiotik dan prebiotik.

Kombinasi probiotik dan prebiotik dalam saluran pencernaan sangat menguntungkan bagi induk semang. Hasil penelitian Awad et al. (2009) menunjukkan bahwa sinbiotik probiotik dan prebiotik mampu meningkatkan secara signifikan pertambahan bobot badan harian broiler. Kombinasi prebiotik inulin bersumber dari umbi dahlia dan probiotik Lactobacillus $s p$. saling menguntungkan atau bersimbiosis dalam tubuh ayam kampung persilangan (Faradila et al., 2016). Penggunaan sinbiotik dapat meningkatkan tinggi vili ileum ayam ras pedaging. Semakin tinggi vili usus halus, maka permukaan absorbsi akan semakin luas, sehingga kecernaan nutrien lebih baik (Hamid et al., 2014).

Berdasarkan permasalahan di atas, maka dilakukan penelitian untuk mengetahui penggunaan starter bakteri asam laktat dan inulin bersumber dari umbi bunga dahlia dalam ransum itik tegal jantan periode starter terhadap ketahanan tubuh, kecernaan nutrien dan produktivitas.

\section{MATERI DAN METODE Itik dan Ransum Penelitian}

Penelitian menggunakan itik tegal jantan umur 8 hari dengan rata-rata bobot badan 40,56 $\pm 2,67$ g sebanyak 96 ekor, dipelihara selama 35 hari. Bahan penyusunan ransum basal meliputi jagung kuning, dedak padi, bungkil kedelai, tepung ikan, mineral dan vitamin yang disusun dengan kandungan protein kasar $19,31 \%$ dan energi metabolis $2.929,98 \mathrm{kkal} / \mathrm{kg}$ (Tabel 1). Umbi bunga dahlia sebagai sumber inulin diberikan dalam bentuk tepung. Starter $B A L$ dan tepung umbi dahlia dicampur sebanyak $20 \mathrm{~g}$ ransum dan diberikan pagi hari, setelah ransum tersebut habis terkonsumsi dilanjutkan dengan pemberian ransum tanpa perlakuan. Air minum disediakan ad libitum.

Tabel 1. Komposisi Ransum dan Kandungan Nutrien Itik Tegal Jantan Periode Starter

\begin{tabular}{|c|c|}
\hline Susunan Ransum & Komposisi Ransum \\
\hline Bahan Pakan & ----------\%--------- \\
\hline Jagung Kuning & 48 \\
\hline Dedak Padi & 25 \\
\hline Bungkil Kedelai & 16 \\
\hline Tepung Ikan & 10 \\
\hline Vitamin dan Mineral & 1 \\
\hline Total & 100 \\
\hline Kandungan Nutrien: & \\
\hline Energi Metabolis ${ }^{2)}$ & $2.929,98$ \\
\hline Protein Kasar ${ }^{1)}$ & 19,31 \\
\hline Lemak Kasar ${ }^{1)}$ & 6,36 \\
\hline Serat Kasar ${ }^{1)}$ & 5,38 \\
\hline Kalsium $^{1)}$ & 1,02 \\
\hline Fosfor $^{1)}$ & 0,66 \\
\hline
\end{tabular}

Keterangan :

${ }^{1)}$ Berdasarkan analisis proksimat di Laboratorium Ilmu Nutrisi dan Pakan, Fakultas Peternakan dan Pertanian, Universitas Diponegoro (2019).

${ }^{2}$ Berdasarkan perhitungan Tabel Hartadi et al. (kkal/kg) (2005). 


\section{Pengambilan Data}

Data yang diukur meliputi konsumsi ransum, kecernaan protein kasar, lemak kasar, serat kasar, asupan protein, rasio heterofil limfosit (HL), konversi ransum dan pertambahan bobot badan. Data kecernaan nutrien diambil pada umur 32-35 hari dengan menggunakan metode total koleksi berdasarkan Sibbald dan Wolynetz (1984). Konsumsi ransum diukur setiap hari selama pemeliharaan. Bobot badan diukur pada awal dan akhir pemeliharaan. Rumus kecernaan protein kasar, lemak kasar dan serat kasar berdasarkan Tilman et al. (1991). menurunkan konsumsi ransum dibandingkan perlakuan lainnya (T0, T1 dan T2). Begitu juga dengan kecernaan protein kasar, serat kasar dan lemak kasar, walaupun T3 tidak berbeda dengan T2, tetapi T3 lebih mampu meningkatkan kecernaan. Nilai kecernaan nutrien pada T3 dapat didukung dengan asupan protein yang tinggi (T3) dibandingkan perlakuan lainnya. Walaupun konsumsi ransum menurun, kecernaan nutrien dan asupan protein mengalami peningkatan terjadi kenaikan aktivitas protease akibat populasi bakteri menguntungkan (bakteri asam laktat) yang menciptakan $\mathrm{pH}$ rendah. Kondisi saluran pencernaan asam berdampak terhadap aktivitas protein.

Tabel 2. Rerata Konsumsi Ransum, Kecernaan Protein Kasar, Serat Kasar, Lemak Kasar dan Asupan Protein pada Itik Tegal Jantan Periode Starter

\begin{tabular}{|c|c|c|c|c|}
\hline \multirow{2}{*}{ Parameter } & \multicolumn{4}{|c|}{ Perlakuan } \\
\hline & T0 & T1 & $\mathrm{T} 2$ & T3 \\
\hline Konsumsi Ransum (g/ekor/hari) & $38,76^{\mathrm{a}}$ & $39,28^{\mathrm{a}}$ & $33,87^{\mathrm{b}}$ & $29,49^{c}$ \\
\hline Kecernaan Protein Kasar (\%) & $59,73^{\mathrm{b}}$ & $62,12^{\mathrm{b}}$ & $73,63^{\mathrm{a}}$ & $73,82^{\mathrm{a}}$ \\
\hline Kecernaan Serat Kasar (\%) & $18,79^{\mathrm{c}}$ & $22,01^{\mathrm{bc}}$ & $26,73^{\mathrm{ab}}$ & $29,70^{\mathrm{a}}$ \\
\hline Kecernaan Lemak Kasar (\%) & $54,55^{\mathrm{c}}$ & $64,20^{\mathrm{b}}$ & $77,61^{\mathrm{a}}$ & $79,82^{\mathrm{a}}$ \\
\hline Asupan Protein $(\mathrm{g})$ & $8,07^{\mathrm{c}}$ & $8,76^{\text {bc }}$ & $9,77^{\mathrm{b}}$ & $11,70^{\mathrm{a}}$ \\
\hline
\end{tabular}

abc Notasi huruf yang berbeda pada baris yang sama menunjukkan perbedaan nyata $(\mathrm{p}<0,05)$.

T0:Ransum kontrol/RK; T1:RK+ starter BAL 2 mL; T2: RK+TUBD 0,8\%; T3:RK+ starter BAL 2 mL+ TUBD 0,8\%

\section{Rancangan Percobaan}

Rancangan percobaan yang digunakan dalam penelitian adalah rancangan acak lengkap dengan 4 perlakuan dan 4 ulangan (masing-masing 6 ekor). Perlakuan yang digunakan sebagai berikut :

$\mathrm{TO}=$ ransum kontrol/RK

$\mathrm{T} 1$ = RK dengan starter BAL $2 \mathrm{~mL}$

$\mathrm{T} 2=\mathrm{RK}$ dengan tepung umbi dahlia $0,8 \%$

$\mathrm{T} 3=\mathrm{RK}$ dengan starter BAL $2 \mathrm{~mL}$ + tepung umbi dahlia $0,8 \%$

Data yang terkumpul diolah dengan analisis ragam pada taraf $5 \%$ untuk mengetahui pengaruh perlakuan terhadap peubah yang diukur. Apabila berpengaruh nyata dilanjutkan dengan uji Duncan pada taraf 5\% (Gaspersz, 1991).

\section{PEMBAHASAN}

Pemberian starter bakteri asam laktat (BAL) dan inulin dari tepung umbi bunga dahlia (TUBD) nyata $(p<0,05) \quad$ meningkatkan kecernaan protein kasar, serat kasar, lemak kasar dan asupan protein, tetapi menurunkan konsumsi ransum (Tabel 2). Pemberian starter BAL $2 \mathrm{~mL}$ dan TUBD sebanyak 0,8\% (T3)
Pemberian starter BAL dan TUBD yang dikombinasikan (T3) mempunyai pengaruh lebih baik dibandingkan tanpa yang dikombinasi ( $\mathrm{T} 1$ dan T2). Starter BAL dan TUBD yang dikombinasikan merupakan sinbiotik yang mampu bersinergi di dalam saluran pencernaan. Penggunaan probiotik dan prebiotik mampu meningkatkan ketahanan inang terhadap patogen eksogenus pencernaan, mengontrol persaingan bakteri (competitive exclusion), menurunkan keracunan metabolisme mikrobial dalam pencernaan dan mengatur sistim imunitas inang (Haryati, 2011).

Kombinasi probiotik dan prebiotik dapat menciptakan competitive exclusion di dalam saluran pencernaan. Proses fermentasi yang tinggi dapat memberikan kontribusi bagi pertumbuhan BAL sehingga kemampuan competitive exclusion lebih besar terhadap Escherichia coli (Krismiyanto, 2015). Kombinasi starter BAL $2 \mathrm{~mL}$ dan TUBD 0,8\% (T3) memiliki kecernaan protein kasar yang tinggi diindikasikan proses pencernaan protein tinggi. Guilloteau et al. (2010) menyatakan bahwa BAL menghasilkan asam rantai lemak pendek, sehingga kondisi $\mathrm{pH}$ saluran pencernaan menjadi menurun, berdampak terhadap 
terhambatnya pertumbuhan bakteri patogen. Penurunan $\mathrm{pH}$ saluran pencernaan dapat meningkatkan aktivitas proteolisis, akibatnya dapat meningkatkan penyerapan protein, sehingga berpengaruh terhadap jumlah nitrogen yang diretensikan (Fanani et al., 2016). Proses fermentasi BAL di dalam saluran pencernaan terutama pada bagian caecum mampu membantu menekan pertumbuhan bakteri patogen.

Sehingga bakteri menguntungkan selain BAL seperti bakteri yang mencerna serat kasar dapat berkembang. Struktur inulin yang masih utuh sampai caecum dapat dimanfaatkan bakteri menguntungkan. Hal ini dapat dilihat (Tabel 2), kecernaan serat kasar yang dikombinasikan (T3) lebih tinggi dibandingkan perlakuan lainnya (T1 dan T2). Sutrisna (2011) menyatakan bahwa itik memiliki kemampuan memanfaatkan bahan pakan berserat tinggi, secara anatomi saluran pencernaan bagian ileum, caecum dan usus besar berfungsi sebagai fermentor yang berpotensi untuk pertumbuhan bakteri selulolitik.

Populasi Escherichia coli yang menurun dapat menciptakan kondisi yang sehat sehingga proses pencernaan di caecum terutama pencernaan serat kasar yang difermentasi oleh bakteri selulolitik. Peran populasi BAL yang meningkat di caecum untuk memecah karbohidrat yang selanjutnya dapat difermentasi oleh bakteri selulolitik (Krismiyanto et al., 2015). Winarsih (2005) menyatakan bahwa peningkatan luas permukaan usus dapat meningkatkan penyerapan nutrien dan menekan pertumbuhan Escherichia coli.

Tabel 3. Rerata Rasio Heterofil/Limfosit (H/L), Konversi Ransum dan Pertambahan Bobot Badan pada Itik Tegal Jantan Periode Starter

\begin{tabular}{lcccc}
\hline \multicolumn{1}{c}{ Parameter } & \multicolumn{3}{c}{ Perlakuan } \\
\cline { 2 - 5 } & T0 & T1 & T2 & $0,63^{\mathrm{b}}$ \\
\hline Rasio H/L & $0,89^{\mathrm{a}}$ & $0,87^{\mathrm{a}}$ & $0,83^{\mathrm{ab}}$ & $2,71^{\mathrm{c}}$ \\
Konversi Ransum & $4,81^{\mathrm{a}}$ & $3,78^{\mathrm{b}}$ & $3,57^{\mathrm{bc}}$ & $283,23^{\mathrm{a}}$ \\
Pertambahan Bobot Badan (g/ekor) & $216,34^{\mathrm{b}}$ & $270,12^{\mathrm{a}}$ & $247,17^{\mathrm{ab}}$ & $28{ }^{2}$
\end{tabular}

${ }^{a b c}$ Notasi huruf yang berbeda pada baris yang sama menunjukkan perbedaan nyata $(\mathrm{p}<0,05)$.

T0:Ransum kontrol/RK; T1:RK+ starter BAL 2 mL; T2: RK+TUBD 0,8\%; T3:RK+ starter BAL 2 mL+

TUBD $0,8 \%$

Berdasarkan Tabel 3 menunjukkan bahwa kondisi yang sehat dapat dilihat dari indikitor tubuh melalui rasio heterofil/limfosit. Kombinasi starter BAL $2 \mathrm{~mL}$ dan inulin sebanyak 0,8\% (T3) lebih rendah dibandingkan $\mathrm{T} 1$ dan $\mathrm{T} 0$. Penambahan starter BAL $2 \mathrm{~mL}$ dan TUBD 0,8\% (T3) dalam ransum mampu memberikan kontribusi saluran pencernaan yang sehat. Fajrih et al. (2014) melaporkan bahwa kondisi saluran pencernaan yang sehat berdasarkan rasio $\mathrm{H} / \mathrm{L}$ mendekati 0,5. Rasio H/L adalah indikator ketidaknyamanan pada unggas, semakin tinggi angka rasio, maka tingkat ketidaknyamanan tinggi pula (Kusnadi, 2008). Rasio H/L pada masing-masing T0, T1 dan T2 lebih tinggi dibandingkan T3. Hal ini disebabkan oleh kombinasi probiotik dan prebiotik di dalam saluran pencernaan yang mampu menciptakan competitive exclusion dibandingkan penambahan masing-masing starter BAL $2 \mathrm{~mL}$ (T1) dan inulin sebanyak $0,8 \%$ (T2). Murwani (2008) menyatakan bahwa melalui competitive exclusion terjadi kompetisi antara bakteri dan organisme tertentu yang mengakibatkan bakteri tidak dapat menempel pada permukaan saluran pencernaan. Bakteri asam laktat menghasilkan senyawa short chain fatty acid sehingga $\mathrm{pH}$ usus menurun dan pertumbuhan bakteri patogen terhambat (Wulansari et al., 2016). Populasi bakteri patogen dalam usus rendah berdampak terhadap kesehatan saluran pencernaan, sehingga tubuh melakukan respon melalui organ limfoid (bursa fabrisius, limpa dan timus) dan rasio HL (Jamilah et al., 2013).

Selain kombinasi starter BAL $2 \mathrm{~mL}$ dan TUBD 0,8\% (T3) memberikan dampak positif terhadap rasio $\mathrm{H} / \mathrm{L}$, tetapi juga terhadap konversi ransum dan pertambahan bobot badan. Indikasi terjadinya peningkatan konversi ransum dan pertambahan bobot badan didukung penyerapan nutrien. Kondisi ini dapat dilihat pada Tabel 2, asupan protein dan kecernaan protein (T3) memberikan dampak positif terhadap konversi ransum dan pertambahan bobot badan. Mookiah et al. 


\section{KESIMPULAN}

Simpulan bahwa kombinasi starter bakteri asam laktat $2 \mathrm{~mL}$ dan inulin dari tepung umbi bunga dahlia $0,8 \%$ (T3) mampu meningkatkan kecernaan protein, lemak, serat kasar, kesehatan tubuh dan performan itik tegal periode starter.

\section{DAFTAR PUSTAKA}

Awad, W. A., Ghareeb, K., Abdul-Raheem S., \& Bohm, J. 2009. Effects of dietary inclusion of probiotic and synbiotic on growth performance, organ weights, and intestinal histomorphology of broiler chickens. Poult. Sci. 88: 49-55.

Direktorat Jenderal Peternakan dan Kesehatan Hewan. 2019. Statistik Peternakan. Kementerian Pertanian, Jakarta.

Fanani, A. F., Suthama, N. \& Sukamto, B.. 2016. Efek penambahan umbi bunga dahlia sebagai sumber inulin terhadap kecernaan protein dan produktivitas ayam lokal persilangan. J. Kedokteran Hewan-Indonesia 10(1):58-62.

Faradila, S., Suthama, N. \& Sukamto, B.. 2016. Kombinasi inulin umbi dahliaLactobacillus sp yang mengoptimalkan perkembangan mikroflora usus dan pertumbuhan persilangan ayam pelungleghorn. J. Veteriner 17(2):168-175.

Gaspersz V. 1991. Metode Perancangan Percobaan. CV Armico, Bandung.

Guilloteau, P., Martin, L., Eeckhaut, V., Ducatelle, R., Zabielski, R. \& Van Immerseel, F. 2010. From the gut to the peripheral tissues: the multiple effects of butyrate. J. Nutr. Res. Rev. 23: 366-384.

Hamid, I. S., Rahardjo B. P. S. \& Gabriela, M.. 2014. Potensi pemberian sinbiotik pada umur yang berbeda pada gambaran histologi ileum ayam pedaging betina. Vet. Med. 7(2): 114-119.

Hartadi, H., Reksohadiprodjo, S. \& Tillman, A. D.. 2005. Tabel Komposisi Pakan Untuk Indonesia. Gadjah Mada University Press, Yogyakarta.

Haryati, T. 2011. Probiotik dan prebiotik sebagai pakan imbuhan nonruminansia. Wartazoa 21(3): 125-135.

Jamilah, Suthama, N. \& Mahfudz,L.D. 2013. Performa produksi dan ketahanan tubuh broiler yang diberi pakan step down dengan penambahan asam sitrat sebagai acidifier. JITV 18(4):251-257.

Krismiyanto, L. 2015. Penambahan Inulin dari Umbi Dahlia (Dahlia variabilis) terhadap
Perkembangan Bakteri Usus Halus dan Produktivitas Ayam Kampung Persilangan. Tesis. Universitas Diponegoro, Semarang.

Krismiyanto, L., Suthama N. \& Wahyuni, H. I.. 2015. Keberadaan bakteri dan perkembangan caecum akibat penambahan inulin dari umbi dahlia (Dahlia variabilis) pada ayam kampung persilangan periode starter. JIIP 24(3):54-60.

Mookiah, S., Sieo, C. C., Ramasamy, K., Abdullah, N. \& Wan Ho Y. 2013. Effects of dietary prebiotics, probiotic and synbiotics on performance, caecal bacterial populations and caecal fermentation concentrations of broiler chickens. J. Sci. Food and Agric. 94(2):341-348.

Patterson, J. A. \& Burkholder. K. M. 2003. Application of Prebiotics and Probiotics in Poultry Production. Poult. Sci. 82:627631.

Sibbald, I. R. \& M. S. Wolynetz, 1984. Estimates or retained nitrogen used to correct estimates of bioavalaible energy. Poult. Sci. 64 : 1506-1513.

Standar Nasional Indonesia. 2018. Pakan Itik Pedaging Starter (SNI 8507:2018). Badan Standarisasi Nasional, Jakarta.

Sutrisna, R. 2011. Pengaruh beberapa tingkat serat kasar dalam ransum terhadap perkembangan organ dalam itik jantan.J. Penelitian Penerapan Terapan 12(1):15.

Tillman, A.D., Hartadi, H., Reksohadiprodjo, S., Prawirokusumo, S. \& Lebdosoekojo, S.. 1991. IImu Makanan Ternak Dasar. Gadjah Mada University Press, Yogyakarta.

Winarsih, W. 2005. Pengaruh Probiotik dalam Pengendalian Salmonellosis Subklinis pada Ayam: Gambaran Patologis Dan Performan. Disertasi. Pascasarjana IPB, Bogor.

Wulansari, Z., Suthama, N. \& Mangisah, I..2016. Pemanfaatan soybean oligosaccharides dari bungkil dan kulit kedelai terhadap ketahanan tubuh ayam broiler. J. Pengembangan Penyuluhan Pertanian 13(23):47-52. 